\title{
DIS GRIEKS VIR MY \\ DIE KLASSIEKE AS METAFOOR VIR DIE UNIVERSITEIT
}

\author{
J C Thom (Universiteit van Stellenbosch)
}

\section{$1 \quad$ Inleiding}

Ek het lank gewik en geweeg oor 'n gepaste onderwerp vir hierdie intreerede. ${ }^{1}$ Die eenvoudigste sou wees om ' $n$ tema te kies wat direk by my eie navorsing aansluit: dit sou dan 'n onderwerp wees wat ek in diepte ken en waaroor ek in alle beskeidenheid meen dat ek wel iets interessants aan u kon meedeel. Aan die anderkant is die voortbestaan van die Klassieke tans by verskeie universiteite in Suid-Afrika onder groot druk: ek het dit dus goedgedink om hierdie geleentheid te benut om saam met $u$ te besin oor die rol en sin van die Klassieke in 'n nuwe SuidAfrika op die vooraand van die derde millenium. Dit is egter vir my duidelik dat die uitdagings waarvoor die Klassieke te staan gekom het, nie beperk is tot hierdie dissipline nie; heelparty daarvan is eweneens van toepassing op die geesteswetenskappe in die algemeen, en inderdaad selfs ook op die universiteit, as akademiese instelling, in die geheel-vandaar die ietwat hubristiese subtitel van my rede.

Om terug te keer na die eerste deel van die titel: Die woord "Grieks" is lank reeds spreekwoordelik vir 'n saak wat heeltemal onverstaanbaar is. ${ }^{2}$ Trouens, die uitdrukking "Dit is Grieks vir my" het reeds hierdie betekenis as Shakespeare dit tong in die kies in Julius Caesar in die mond van Casca lê wat slegs Latyn praat, en nie Cicero se Grieks verstaan nie:

Cassius [aan Casca] Did Cicero say anything?

Casca. Ay, he spoke Greek.

Cassius. To what effect?

Casca. Nay, an I tell you that, I'll ne'er look you i' the face again: but those that understood him smiled at one another, and shook their heads; but, for mine own part, it was Greek to me.

(Julius Caesar, Act 1, Scene 2)

Shakespeare dryf hier die spot met die eenvoudige Casca, maar dalk ook met die pretensies van die pedantiese Cicero en sy geleerde vriende en hulle Griekse "binnekring" grappies. Volgens Shakespeare se tydgenoot, die digter Ben Jonson, het Shakespeare self "small Latin and less Greek" gehad. ${ }^{3}$

1 Hersiene weergawe van 'n intreerede gelewer te Stellenbosch op 18 November 1997. Daar is besluit om nie die aard van die rede as rede te wysig nie, omdat dit dan te veel van sy karakter sou verloor.

2 Kyk WAT, s.v. Grieks II.

3 Ben Jonson, To the memory of my beloved, the author Mr. William Shakespeare and what he hath left us, line 31 . 
Dis maar 'n hanetreetjie om van "onverstaanbaar" na "onsinnig, betekenisloos", te beweeg. Dit wat ek nie kan verstaan nie, het geen betekenis vir my lewe nie, is derhalwe vir my irrelevant. Om nog 'n landgenoot van Shakespeare, die bekende 18de-eeuse woordeboekmaker Dr Samuel Johnson aan te haal: "Greek, Sir, is like lace; every man gets as much of it as he can." 4 In die hoogbloei van die Verligting is hierdie uitspraak as hoë lof bedoel, maar "kant" kan heel gou as blote versiering vir rykes, as 'n onnodige luukse, verstaan word. Die einste Dr Johnson het dus ook beweer: "A man is in general better pleased when he has a good dinner upon his table, than when his wife talks Greek." 5

Die Klassieke as irrelevante luukse: dit is die aantyging waarteen ons 'n verweer moet vind.

\section{Die probleem: die relevansie van die Klassieke}

Soos u weet, was 'n goeie klassieke agtergrond nie net in Dr Johnson se tyd nie, maar tot so onlangs as die begin van hierdie eeu veral in die Europese tradisie 'n kenmerk van 'n beskaafde en goed opgevoede persoon. Studie van die Klassieke het trouens die kern van die sekondêre en tersiêre onderwysleerplanne vir kinders van die hoër stande uitgemaak. Die hoë waarde wat aan die literêre, morele, filosofiese en historiese nalatenskap van die Grieke en Romeine geheg is, het dit die basiese verwysingsraamwerk van die beskaafde mens gemaak. Die moeitevolle aanleer van die tale Grieks en Latyn is daarbenewens as uitstekende intellektuele dissipline en 'n belangrike hulp in die morele vorming van jongmense beskou.

Die Klassieke het ook nog hier aan die Kaap en op Stellenbosch in die ontstaanstyd van die Universiteit dieselfde hoë aansien geniet. Die Raad van Eksaminatore wat in 1858 ingestel is en die mag gehad het om sertifikate uit te reik wat later grade sou word, het bevind dat 'n studie van die Klassieke bydra tot die gesonde ontwikkeling van die student se intellektuele vermoëns, en hom in staat stel "to take a high rank in the profession whatever that may be, which he shall then adopt as the serious business of his life" ${ }^{6}$ Dieselfde sentiment vind ons by prof John Murray, in 'n rede gehou by die inwyding van die Kweekskool in 1859:

[D]ie beoefening van die ou klassieke [word] deur die hele beskaafde wêreld beskou as die voortreflikste middel ter ontwikkeling van die gees, nie alleen ter wille van die kennis wat daardeur verkry word nie, maar ook uit hoofde

Boswell's Life of Johnson, vol. 4, p.23.

Boswell's Life of Johnson, vol. 1, p.122 n.4.

A S Kidd, The origins of the S.A. university system 1850-1875 (Grahamstad: Grocott \& Sherry, 1923) 15; aangehaal deur Smuts (1960:16). 
van die gesonde dissipline waaraan die jongmens hierdeur sy denkvermoëns moet onderwerp.... ${ }^{7}$

Grieks en Latyn was dus tot aan die begin van hierdie eeu vereiste vakke vir toelating tot die Victoria-Kollege; Latyn as verpligte vak is eers in 1918 afgeskaf.

Met die toenemende belang van die natuurwetenskappe en moderne tale, en die selfstandig-wording van 'n wye verskeidenheid nuwe dissiplines het die rol van die Klassieke in hoër onderwys geleidelik kleiner en kleiner geword, in so 'n mate dat Grieks en Latyn vandag dikwels as blote ondersteuningsvakke vir teologie en die regte beskou word. Mense sien die belang van die tale as vaardighede in diens van ander wetenskappe of, veral wat Latyn betref, as 'n belangrike basis vir moderne tale soos Engels of Frans. Die waarde van die Klassieke as draer van 'n kultuurwêreld, as uitdrukking van waardes en denke, word egter dikwels buite rekening gelaat.

Een van die redes hiervoor is die relatief hoë moeilikheidsgraad en die steil en lang leerkurwe van Grieks en Latyn. Omdat die meeste studente eers op universiteit met die tale kennis maak, neem dit betreklik lank voordat die tale self "deursigtig" word en 'n mens die wêreld wat daardeur tot uitdrukking kom, kan begin waardeer. Een Stellenbosse student, 'n sekere J V Brink, het in die Studente-Kwartaalblad in 1906 die probleem só beskryf:

The mastering of the Classics has been likened to the slow and laborious ascent of a steep mountain, whose summit looks down upon a fair landscape. What a pity it is that so many turn back faintheartened when only halfway up the slope, and are never able to survey the fair landscape of modern literature from the vantage point of classical learning (Smuts 1966:34).

'n Verdere faktor wat meewerk tot 'n grotendeels instrumentalistiese siening van die klassieke tale, is 'n postmodernistiese skeptisisme met betrekking tot die waarde van klassieke kultuurgoedere. Die Latynse woord classicus beteken oorspronklik "dit wat tot die eerste klas behoort", en later "goed genoeg om as maatstaf gebruik te word", d.w.s. "normatief" (Highet 1949:228). Sedert die Renaissance was die normatiewe tekste en kunswerke waarmee 'n opgevoede persoon vertroud behoort te wees en waaraan ander kultuurgoed gemeet kan word, veral die nalatenskap van die antieke Grieke en Romeine. In die postmoderne tyd is die konsep van algemeengeldige norme aan die hand waarvan sekere kulturele tradisies en kultuurprodukte bo ander verkies word, egter prinsipieel verdag. Hoekom moet ons kultuurgoed van twee- of selfs drieduisend jaar gelede bestudeer? As een teks so goed as ' $n$ ander is, moet ons nie liewer ons aandag wy aan werke wat makliker toeganklik is nie? Gepaardgaande hiermee vind 'n mens by vele, ook binne die universiteits-

7 "[D]e beoefening der oude klassieken [wordt] door de geheele beschaafde wereld beschouwd als het voortreffelijkste middel ter ontwikkeling van den geest, niet alleen om den wille van de daardoor verkregene kennis, maar ook uit hoofde van de gesonde tucht waaraan de jongeling alsdan zijne denkvermogens onderwerpen moet..."; aangehaal deur Smuts (1966:13). 
gemeenskap, 'n gebrekkige historiese bewussyn, wat meebring dat die waarde van 'n gegronde kennis van die verlede en die belang daarvan om onsself te verstaan, misken word.

Teen hierdie agtergrond moet ons dus opnuut die vraag na die sin en relevansie van die Klassieke beantwoord. Ons kan vrae soos "Watter nut het die Klassieke vir 'n mens? Wat kan 'n mens daarmee maak? Wat dra dit by tot die ontwikkeling van die breëre Suid-Afrikaanse samelewing?" nie meer eenvoudig van die tafel vee nie. Dit is egter duidelik dat die relevansie-vraag vandag nie net aan die Klassieke gestel word nie: in die Mail and Guardian is onlangs onder die opskrif "Social sciences under pressure" berig dat "the South African Student's Congress are already questioning the relevance of courses like biblical studies and anthropology". Kenmerkend van die verwagtinge wat tans aan universiteitsonderwys gestel word, vra die SASCO-woordvoerder waarom antropologie nie kan meewerk om etniese twiste op te los nie. ${ }^{8}$ Selfs in die natuurwetenskappe sou sommige kon wonder oor die relevansie van sterrekunde of navorsing oor die geslagslewe van 'n woestyninsek in die Namib.

Hierdie tipe bevraagtekening berus op die foutiewe veronderstelling dat die universiteit hom in die eerste plek behoort in te stel op "relevante' of 'toepasbare' of 'nuttige' of "praktiese' kennis" wat sal lei tot die "praktiese bemagtiging" van die student en die gemeenskap, in plaas van op "kennis as 'n waarde in sigself". Die uitdaging waarvoor vrae soos hierbo genoem die universiteit stel, is uiteindelik, in die woorde van H W Rossouw in 'n onlangse gelyknamige opstel, niks minder nie as "die behoud van die akademiese etos" (Rossouw 1997, veral pp.2-3). Die vraag na die relevansie van die Klassieke hang ten nouste saam met die vraag na die wese van die universiteit self.

\section{Die antieke debat oor hoër opvoeding}

\subsection{Sokrates en die Sofiste}

Vrae oor die rol en relevansie van hoër onderwys is egter glad nie so modern as wat 'n mens mag meen nie: heelparty van die tersaaklike vraagstukke is alreeds in die 5de eeu v.C. in Griekeland aan die orde gestel. Die 5de eeu word getipeer as die tyd van die Griekse Verligting: dit was 'n tyd waarin demokrasieë hul beslag gekry het, 'n tyd waarin wegbeweeg is van tradisionele godsdienstige en sosiale norme en nuwe vorme ondersoek is, ' $n$ tyd waarin individualisme in produktiewe spanning teenoor groepsgebondenheid gestaan het, 'n tyd van ekonomiese ontwikkeling en entrepreneurskap, kortom, 'n tyd van verandering en kreatiwiteit.

Ook die onderwys is gekenmerk deur 'n nuwe etos, wat veral deur die Sofiste verteenwoordig is. ${ }^{9}$ Die tradisionele Griekse opvoeding of paideia het drie breë

$8 \quad$ Weekly Mail and Guardian, October 24 to 301997 , p.51.

9 Algemene oorsig in Marrou 1982:46-60; Joint Association of Classical Teachers 1984:172-177. 
areas behels: basiese geletterdheid en syfervaardigheid, musiek en liggaamlike opvoeding. Die doel was om die fundamentele waardes van die stadstaat, die polis, vas te lê en om van die studente goeie burgers te maak, eerder as om selfstandige denke te stimuleer of om studente vir 'n beroep voor te berei. In letterkunde en musiek is byvoorbeeld op die memorisering van tradisionele digters en musikale vorme gekonsentreer, wat die studente se karakters moes vorm en van hulle "beskaafde en opgevoede" persone moes maak, instede van aandag te gee aan teorie en analitiese vaardighede. ${ }^{10} \mathrm{Die}$ Sofiste, daarenteen, het studente nuwe retoriese vaardighede en argumentatiewe strategieë geleer waarmee hulle hulself as burgers in die howe en politieke debatte kon handhaaf. As rondreisende dosente het hulle hulle nie gebonde gevoel deur die morele en sosiale norme van bepaalde gemeenskappe nie; hulle het inteendeel juis die relatiwiteit van hierdie norme ervaar en gepropageer. Een van die belangrikste Sofiste, Protagoras, was dan ook bekend vir sy uitspraak "Die mens is die maatstaf van alle dinge", wat as die basiese beginsel van 'n morele relativisme gegeld het. 'n Verdere faktor wat die Sofiste verdag gemaak het, is die feit dat hulle vir die eerste keer geld vir hulle onderrig gevra het-in sommige gevalle reusagtige bedrae. Opvoeding word nou 'n kommoditeit met 'n besliste ekonomiese voordeel vir die dosent, wat die agterdog laat posvat het dat hy ongeag die waarheid aan sy studente sal leer wat hulle graag wil hoor, in plaas van wat hulle behoort te weet. Die natuurfilosowe van die tyd, die sogenaamde Presokratici, het met hulle nuwe onpersoonlike kosmologiese modelle verder daartoe bygedra om tradisionele godsdienstige opvattinge oor die ontstaan en goddelike bestuur van die wêreld te ondermyn.

Ons vind 'n kostelike uitbeelding vanuit 'n lekeperspektief van die sosiale spanninge en kontradiksies wat hierdie nuwe hoër onderwys tot gevolg gehad het in Aristofanes se komedie Die wolke, 'n drama wat in 423 v.C. in Atene opgevoer is. ${ }^{11}$ Die hoofkarakter, Strepsiades, is 'n armsalige plattelandse omie wat deur sy vrou en perdemal seun se spandabelrigheid diep in die skuld gedompel is. Hy kry egter 'n blink ingewing: hy sal sy seun Feidippides verder laat leer en só hulle probleme oplos. Hy het immers van 'n universiteit gehoor-Aristofanes noem dit spottend 'n frontistêrion, 'n "dink-plek"-waar die professor, Sokrates, jou leer om enige hofgeding te wen deur selfs 'n slegte saak só oortuigend te beargumenteer dat jy altyd die oorhand oor jou opponente kry. Met só 'n opvoeding in retoriek agter die blad is Strepsiades seker sal sy seun hulle skuldeisers kaf draf. Die bruingebrande en modebewuste Feidippides is egter minder entoesiasties: dit sal sy beeld skaad om onder die bleek en verslonste studente gesien te word. Hy weier dus botweg om hom by die dink-plek te gaan inskryf. Al uitweg is dat Strepsiades op sy oudag self student word.

Hy word eers deur 'n ander student op 'n toer van die dink-plek geneem. Strepsiades is van die staanspoor af hoogs beïndruk met die "misteries" wat hy in die dink-plek hoor en sien; ek noem slegs enkele voorbeelde:

10 Kyk in die algemeen Marrou 1982:36-45.

11 Teks en kommentaar deur Dover (1968). 
- In "entomologie" meet hulle die afstand wat 'n vlooi spring deur vir hom pantoffels van was te maak, dit uit te trek en die afstand dan met die waspantoffels te meet (rr.144-152).

- Strepsiades sien vir die eerste keer in die "kartografie"-klas 'n kaart van Griekeland en is hoogs ontsteld dat hulle vyande, Sparta, so naby aan Atene op die kaart is. Hy stel voor dat die professore dit verder weg "skuif". Toe die student antwoord dat dit nie moontlik is nie, is Strepsiades se lakoniese kommentaar: "Julle sal nog spyt wees!" (rr.206-217).

- Professor Sokrates bestudeer "die dinge in die lug" vanuit 'n mandjie waarin hy opgehys is, sodat sy subtiele denke nie deur swaartekrag grondtoe getrek word nie (rr.218-233).

Die absurditeite waarmee die dosente hulle besig hou, skrik Strepsiades glad nie af nie: professore wat só slim is, sal natuurlik vir hom veel kan leer wat van nut sal wees vir die alledaagse lewe (vgl. rr.167-168, 180-183)!

$\mathrm{Na}$ dié indrukwekkende toer is Strepsiades oorgehaal om met sy kursus te begin. Sy hoofvak, Retoriek, word heel dramaties en didakties stimulerend aangebied deur twee karakters wat onderskeidelik die Regte en On-regte Argumentvoering uitbeeld. Eersgenoemde staan argumentvoering voor wat op tradisionele morele waardes en norme berus. On-regte Argumentvoering daarenteen relativeer en dekonstrueer hierdie morele argumente en gebruik hulle om presies hulle teendeel te bewys (rr.889-1104).

Hoewel Strepsiades intens geïnteresseerd is in die vak, sak hy die eksamen en moet hy die dink-plek verlaat. Met vele dreigemente haal hy nou tog sy seun oor om te gaan studeer. Intussen hou hy sy krediteure op 'n afstand deur hulle met dieselfde akademiese slimmighede en woordspeletjies as wat hy by Sokrates gehoor het, te verwar. Feidippides kom sy kursus in On-regte Argumentvoering deur, maar helaas! hy gebruik sy nuutverworwe vaardighede nou om sy pa se gesag te ondermyn, in plaas daarvan om hom te help. Hy argumenteer byvoorbeeld dat as ouers hulle kinders as hulle klein is ter wille van hulle eie beswil 'n pak slae gee, kinders hulle ouers later weer moet pakgee as hulle begin kinds word.

Omdat hy bang is vir 'n pak slae, laat Strepsiades Feidippides begaan, maar uit weerwraak brand hy die dink-plek af.

Daar is klaarblyklik 'n hele aantal raakpunte tussen die uitbeelding van hoër onderwys in Aristofanes se Wolke en die huidige debat:

- In die eerste plek is daar die spanning tussen Strepsiades se verwagting dat 'n universiteitsopleiding van direkte praktiese nut sal wees om sy alledaagse probleme op te los, aan die een kant, en die "onbetrokke" en selfs "irrelevante" akademiese aktiwiteite van die universiteit waar kennis om kennis ontwil nagevors word, en nie ter wille van die praktiese toepassing daarvan nie, aan die ander kant. Die koor en beskermgodinne na wie die komedie vernoem is, naamlik die Wolke, simboliseer sowel dat die akademici "met hulle koppe in die 
wolke" leef-dit word beklemtoon deurdat Sokrates sy navorsing in 'n mandjie in die lug doen-as die insubstansiële aard van hulle denke en navorsing (vgl. Dover 1968:1xvii-lxviii).

- Die kritiese en retoriese vaardighede wat Feidippides aan die universiteit leer, het nie 'n eenduidige aanwending nie en kan nie vasgepen word om slegs een doel te dien nie-dit kan sowel vír as teén Strepsiades se belange aangewend word.

- Akademiese vryheid behels onvermydelik dat 'n universiteit nie slegs die waardes van 'n samelewing sal uitbou en bevorder nie, maar by geleentheid dit ook sal bevraagteken en selfs sal ondermyn. Die universiteit as "dink-plek" is inderdaad 'n gevaarlike instelling waarin nuwe opvattings en nuwe, alternatiewe waardes tot stand kan kom wat die bestaande orde kritiseer.

As ek Strepsiades se ervaring met hoër onderwys ietwat simplisties mag saamvat: terwyl hy slegs die hoe wou leer (hoe raak ek van my skuld ontslae, hoe wen ek my hofgeding), het hy agtergekom dat die wat minstens net so belangrik is (wat maak ek met my opleiding, wat is die basis en inhoud van my argumente).

'n Mens moet natuurlik in gedagte hou dat Aristofanes se Wolke as karikatuur van die hoër opvoeding van sy tyd, ook in bepaalde opsigte 'n vertekening van die werklikheid is. Veral die uitbeelding van Sokrates verskil drasties van wat ons uit ander bronne van Sokrates weet. Die "Sokrates" van die Wolke is klaarblyklik bedoel as 'n karikatuur van die akademikus in die algemeen (Dover 1968:xxxiilvii).

Ons vind ' $n$ ander perspektief op dieselfde antieke debat in verskeie van Plato se dialoë. In een hiervan, die Protagoras, word die debat tussen Sokrates en die Sofiste oor die doel en fokus van hoër opvoeding op meesterlike wyse uitgebeeld. ${ }^{12}$ Die gebeure wat in die dialoog gedramatiseer word, speel af ongeveer 433 v.C., d.w.s. sowat tien jaar voor die Wolke.

Hippokrates, 'n jong vriend van Sokrates, klop hom douvoordag op met die versoek om hom aan Protagoras, die beroemde Sofis wat pas in Atene aangekom het, voor te stel, sodat hy by hom kan gaan studeer. Vir hierdie voorreg is Hippokrates bereid om alles te betaal wat hy het, al moet hy ook geld van sy vriende leen. Sokrates maan hom egter om eers goed na te dink oor wat hy by Protagoras gaan leer voordat hy 'n oorhaastige besluit neem. Met 'n bietjie aanporring van Sokrates, laat blyk Hippokrates dat hy nie by Protagoras wil gaan studeer om self ook 'n Sofis, d.w.s. 'n professionele dosent, te word nie, net soos hy ook nie kitaarlesse geneem het om 'n professionele kitaarspeler te word nie; hy wil eerder 'n algemene opvoeding by hom kry in dit waarvoor 'n Sofis bekend is, naamlik om 'n goeie spreker te wees. Sokrates wil nou egter weet waaróór leer 'n Sofis 'n mens om goed te praat: wat is die inhoud van die kennis wat 'n mens by hom kry? Volgens hom is 'n Sofis, as leermeester, 'n handelaar in kos vir die siel; voor 'n mens sy

12 Vir 'n oorsigtelike bespreking, sien Guthrie 1975:213-235. Kyk ook Guthrie 1969. 
ware koop moet jy weet of dit goed of sleg is vir jou siel. As handelaar probeer die Sofis sy ware verkwansel onafhanklik van die kwaliteit daarvan; 'n mens kan jou dus nie slegs op sy eie self-aanbeveling verlaat nie.

Sokrates en Hippokrates besluit dus om eers Protagoras uit te vra oor sy kursus, voordat Hippokrates by hom as student inskryf. Op Sokrates se vraag wat Hippokrates daarby sal baat as hy hom by Protagoras aansluit, antwoord laasgenoemde dat hy elke dag ná 'n kursus by hom 'n beter mens sal wees as die vorige. Goed en wel, sê Sokrates, enige onderwyser kan immers daarop aanspraak maak dat sy student van een dag na die volgende "slimmer" sal wees. In watter opsig sal Hippokrates egter beter word as hy by Protagoras leer? Protagoras antwoord dat hy nie soos ander onderwysers sy studente dwing om eers onnodige voorvereiste vakke soos wiskunde, sterrekunde en musiek te leer nie, maar dat sy onderrig geheel en al praktykgerig is: hulle leer om met diskresie hulle persoonlike sake en dié van die staat te kan hanteer, om 'n goeie spreker en invloedryke leier te wees; kortom, hy leer hulle vaardigheid (technē) en uitnemendheid (aretē) in burgerskap en politiek.

In die res van die dialoog argumenteer Sokrates en Protagoras oor die moontlikheid al dan nie om vir iemand uitnemendheid te leer, en indien wel, wat die aard van uitnemendheid is. Hier kan ek slegs enkele hooftrekke van hulle debat uitlig. ${ }^{13}$ Om hierdie debat te begryp is dit belangrik om in gedagte te hou dat die Griekse woord vir uitnemendheid, arete, tegelyk ook morele deug beteken. Protagoras voer aan dat sosiale en politieke uitnemendheid of deugde nie aangebore eienskappe is nie, maar vaardighede wat die mens met verdrag as deel van sy beskawingsgeskiedenis opgedoen het ten einde in 'n groep te kan oorleef. Hy as Sofis hoef dus nie hierdie deugde van nuuts af vir sy studente te leer nie, omdat hulle dit as lede van 'n beskaafde gemeenskap reeds ken. Hy hoef slegs hulle reeds verworwe kennis te verfyn.

Sokrates dui aan dat die logiese gevolg van die Sofistiese leer 'n lewe gebaseer op ' $n$ hedonistiese berekening is, naamlik die maksimalisering van 'n mens se persoonlike plesier en bevrediging (Guthrie 1975:233). Hy argumenteer dat die sogenaamde politieke deugde soos dapperheid en geregtigheid nie van die ander deugde te skei is nie, en dat alle deugde uiteindelik op kennis of wysheid berus. Om 'n uitnemende of deugsame lewe te voer behels meer as om te weet hoe om jou in bepaalde omstandighede ten beste te gedra, watter voordeel om na te strewe en watter nadeel om te vermy; dit benodig insig in die vaste en onveranderlike morele norme waarop ' $n$ mens jou handeling moet baseer. Die uiteindelike doel van opvoeding behoort dus kennis van die goeie, 'n voortdurende strewe na wysheid te wees.

Om die verskil tussen die twee opvoedingsfilosofieë weereens op 'n oorvereenvoudigde wyse op die spits te dryf: 'n Sofistiese opvoeding het ten doel om van mense suksesvolle burgers te maak; dit leer vir studente die politieke en

13 Ek volg hier die interpretasie van Guthrie (1975:216-235). 
retoriese vaardighede wat hulle onmiddellik benodig om leiers in hulle gemeenskappe te wees. Sokrates daarenteen, wil sy studente help om die basiese en tydlose beginsels van morele handeling te ontdek en hulle eie te maak; dit gaan vir hom wesenlik om die ontdekking van die waarheid self en van waardes wat in die waarheid gefundeerd is en as oriënteringsbeginsels van 'n mens se lewe kan geld.

\subsection{Philodemus}

Die debat tussen Plato en die Sofiste, oftewel tussen filosofie en retoriek, het hom met gereelde tussenposes in die geskiedenis van die filosofie herhaal, en is tans weer aktueel. Voordat ons na die hede terugkeer, wil ek kortliks u aandag vra vir 'n derde antieke teks wat oor opvoeding handel, naamlik Philodemus se boek Oor openhartige kritiek.

Philodemus, 'n tydgenoot van Cicero, was 'n Epikurese literator en filosoof wat in die eerste eeu v.C. in Suid-Italië in Herculaneum, naby Napels, geleef het en 'n groep studente om hom verenig het. ${ }^{14} \mathrm{Hy}$ het 'n breë geesteswetenskaplike belangstelling gehad: behalwe dat hyself gedigte geskryf het, het hy boeke geskryf oor retoriek, estetika, poëtiek, literêre kritiek, musiek, sielkunde, teologie, etiek, logika en geskiedenis van die filosofie. Sy werk getitel Oor openhartige kritiek is in feite 'n handleiding vir dosente oor die filosofie van hoër onderwys en die begeleiding van studente. ${ }^{15}$ Soos die titel aandui, is kritiek 'n sleutelterm in sy onderwysfilosofie. Die Griekse woord wat hier met "openhartige kritiek" vertaal word, parrēsia, kan egter ook weergegee word as "openheid" of "vrymoedigheid"; hoewel die kritiese aspek in hierdie werk vooropstaan, dui die woord eweneens op die openheid wat daar tussen vriende en gelykes op grond van wedersydse vertroue bestaan. (In antieke Atene was 'n burger se parrēsia byvoorbeeld uitdrukking van sy demokratiese reg op vryheid van spraak.)

Volgens Philodemus kan studente slegs intellektueel en geestelik vordering maak as hulle denke én dade voortdurend aan ingrypende en deurdringende kritiese bespreking in 'n konteks van openheid en vryheid onderwerp word. Die kuns vir die dosent bestaan egter daarin om in 'n spesifieke situasie vir 'n bepaalde tipe student die regte vorm van kritiek te gee: vir skugter studente met min selfvertroue moet ' $n$ mens sagkens kritiseer; vir ander is selfs die grofste vorm van kritiek nie sterk genoeg medisyne nie. Vroue moet anders hanteer word as mans, omdat hulle kritiek minder goed verwerk; ouer en gesiene persone voel in hulle eer gekrenk as hulle gekritiseer word, en moet dus ook met omsigtigheid benader word. Sommige studente moet in die openbaar aangespreek word, ander privaat; sommige moet kaalkop die waarheid gesê word, terwyl ander liefs indirek gelei moet word, soos

14 Sien Oxford classical dictionary, s.v. Philodemus; meer besonderhede met resente literatuur in Erler 1994:289-362.

15 'n Nuwe teks met vertaling, inleiding en kort aantekeninge deur D Konstan, D Clay, C E Glad, J C Thom en J Ware verskyn eerdaags. 
om 'n bepaalde fout uit te wys deur dit aan die hand van 'n fiktiewe situasie te beskryf. Aanmoediging, erkenning en lof is ook in bepaalde omstandighede meer effektief as kritiek. Kritiek is egter nie 'n eenrigtingproses nie. Studente word aangemoedig om ook mekaar én hulle dosente te kritiseer; die uiteindelike doel is 'n gemeenskap van "filosowe" wat mekaar onderling help om geestelike en intellektuele volwassenheid te bereik.

Die interessante van Philodemus se benadering is dat dit die ideale van die filosowe soos verteenwoordig deur Plato en Sokrates en dié van die Sofiste verenig. Net soos Plato is sy doelwit dat studente insig in die waarheid moet hê en dat hulle lewens in bepaalde morele waardes gefundeer moet wees, maar om hierdie doel te bereik moet die retoriese vaardighede van die Sofiste aangewend word: oorreding en kritiek is 'n tegniek waarmee die waarheid ontdek word en waardeur studente tot die toe-eiening van bepaalde waardes gelei kan word. ${ }^{16}$ In hierdie proses moet die pragmaties-retoriese vereistes van situasiebetrokkenheid en aanpassing by die behoeftes van die gehoor deeglik in gedagte gehou word. Verder van belang is die sosiale en interaktiewe karakter van die studente en dosente se intellektueelgeestelike ontwikkeling.

\section{$4 \quad$ Die rol van die Klassieke vandag}

Met hierdie antieke perspektiewe op hoër onderwys in gedagte, wil ek in die laaste deel van my rede enkele opmerkings maak oor die aard van die universiteit ${ }^{17}$ en dan afsluit met 'n paar gedagtes oor die waarde van die Klassieke vandag.

\subsection{Die wese van die universiteit}

Universiteite word tereg as nasionale bates beskou wat 'n belangrike bydrae te lewer het tot die ontwikkeling van die land. Die gevaar bestaan egter dat universiteite sal toegee aan die druk om slegs te konsentreer op dié kennisinhoude en vaardighede wat van direkte toepasbare nut is en wat op konkrete en sigbare wyse bydra tot die oplossing van praktiese probleme. Die eiesoortige waarde van die universiteit as akademiese instelling is juis dat dit ruimte laat vir refleksie en afstandneming, dat nie ingestel is op "instant gratification" en kitsoplossings nie. Die universiteit behoort by uitnemendheid 'n tuiste te wees vir "scholarship"-n woord wat teruggaan op die Griekse woord schole, wat "vryheid van normale verpligtinge"

16 Kyk veral Philodemus Oor openhartige kritiek fr. 1, met die literatuurverwysings in Konstan et al. 1998:27 n.5.

17 Dit sou vermetel van my wees om breedvoerig uit te wei oor wat 'n universiteit is en behoort te wees; ander geleerdes, soos H W Rossouw, het dit reeds veel bekwamer gedoen as wat ek ooit kan. Kyk Rossouw 1980; 1993; en veral 1997. Die rede getitel "The making of a university" wat prof S J Shand by geleentheid van die aanneming van die Universiteit van Stellenbosch Wet in 1916 gelewer het, bly ook nog van belang. 
beteken; ' $n$ tuiste dus vir besinning en nadenke ten einde insig in die wêreld en die wese van dinge te verwerf, en nie slegs nuttige feite te versamel of mense vir 'n beroep voor te berei nie. In Aristofanes se terminologie: 'n universiteit is 'n frontistērion, 'n "dink-plek", en nie 'n praktērion, 'n "doen-plek", nie.

So ' $n$ akademiese instelling beteken natuurlik nie 'n vryblywende ivoortoringbestaan nie; 'n kritiese afstand van die praktyk maak dit trouens juis moontlik om kreatief nuwe samehange en betekenisverbande in die werklikheid te ontdek. Universiteitsonderrig en -navorsing behoort dus ook in gesonde waardes gefundeer te wees en daarna strewe om nuwe lewensin en waardes te ontsluit. 'n Waardevrye akademie sal gou blyk waardeloos te wees. Dit hou ondermeer in dat daar keuses gemaak moet word: nie alle tradisies of kennisinhoude of navorsingsprojekte is ewe waardevol nie. 'n Tweede implikasie is dat die akademie altyd 'n morele dimensie het: opvoeding moet met verantwoordelikheid gepaard gaan en behoort 'n verantwoordelikheidsbesef ten opsigte van jouself en die wêreld wat bestudeer word, aan te kweek. Beide hierdie dimensies word treffend in ons universiteitsleuse vervat: Pectora roborant cultus recti, "Die regte opvoeding versterk die karakter." 18 Hoewel "scholarship" dikwels teenoor vaardighede gestel word-daar is byvoorbeeld die afgelope maand ' $n$ konferensie oor hierdie tema in Brittanje gehou ${ }^{19}$ -is dit natuurlik ' $n$ valse teenstelling. Dit word die universiteite en veral die humaniora dikwels verwyt dat hulle nie genoeg praktykgerig is nie, dat hulle studente nie beroepsvaardighede leer nie. Dit is wel so dat die geesteswetenskappe én ander basiese wetenskappe dikwels nie beroepspesifieke vaardighede in die leerplan het nie. Akademiese vaardighede is egter van 'n ander aard: dit behels juis die vermoë om te analiseer en te abstraheer, om 'n saak van verskillende kante te bestudeer, om 'n kritiese openheid teenoor 'n probleem te behou en nuwe, kreatiewe oplossings te soek. Op die langduur, meen ek, is dit juis hierdie vaardighede wat geykte samelewings- en beroepspatrone kan deurbreek en nuwe, onverwagte antwoorde kan bied.

\subsection{Die waarde van die Klassieke}

Wat is dan die rol wat die Klassieke aan so 'n universiteit te speel het? In die eerste plek moet daarop gelet word dat die waarde van die Klassieke nie saamval met die praktiese nut en toepasbaarheid daarvan nie. Natuurlik glo ek dat Grieks en Latyn van onontbeerlike praktiese betekenis vir predikante en regsgeleerdes is; ek sou

18 Die leuse kom oorspronklik uit Horatius se Carmina 4.4.34: rectique cultus pectora roborant. Die ommekeer in woordorde beklemtoon m.i. die feit dat dit pectora, karakter, is wat deur opvoeding versterk word. Die leuse bevat verder moontlik ' $n$ sinspeling wat in vertaling verlore gaan: roborant sinspeel op quercus robur, die akkerboom waarvoor Stellenbosch bekend is.

"Skills versus Scholarship in arts and humanities higher education"-A one-day conference on Saturday 11 October 1997 at The Open University, Walton Hall, Milton Keynes. 'n Kennisgewing oor die konferensie het verskyn in Humanist Discussion Group, vol. 11, no. 287 <http://www.kcl.ac.uk/humanities/cch/humanist>; 23 September 1997. 
graag wou sien dat teologie-studente selfs meer blootstelling aan Grieks moet kry as wat tans die geval is, en dat meer regstudente ná die annvanklike euforie oor die afskaffing van Latyn as verpligte vak weer die waarde daarvan vir hulle beroep sal besef. Hierdie praktiese aanwendingsmoontlikhede van die klassieke tale verteenwoordig egter maar 'n betreklik geringe aspek van die waarde van die Klassieke as akademiese dissipline. Ek wil hierdie waarde in terme van twee perspektiewe bespreek: enersyds in terme van die vaardighede wat daardeur ontwikkel word en andersyds in terme van die inhoudelike betekenis daarvan.

Omdat die Klassieke 'n hele kultuurhistoriese wêreld tot studie-objek het en nie slegs ' $n$ faset daarvan nie, behels dit tradisioneel 'n wye verskeidenheid intellektuele en fisiese vaardighede: vaardighede wat met die vasstelling en interpretasie van tekste te make het, soos taal- en letterkunde, paleografie, tekskritiek, epigrafie en papirologie; historiese vaardighede, soos die versameling, analise, vergelyking en interpretasie van historiese gegewens; en vaardighede wat op die hantering en interpretasie van artefakte soos munte, vase, argitektuur en kunswerke gerig is. Hoewel daar vandag kwalik tyd is om studente met al hierdie vaardighede deeglik vertroud te maak, maak hulle nogtans met 'n wye verskeidenheid daarvan kennis: verskillende invalshoeke word immers benodig om 'n antieke teks, artefak, gebruik of historiese feit te verstaan. Die beswaar dat die vakspesifieke vaardighede wat die Klassieke vereis, teveel tyd verg, word toenemend ondervang deur nuwe ontwikkelinge op rekenaartegnologiese gebied: onderrig- en ondersteuningsmateriaal op $\mathrm{CD}$, sowel as toegang wat die Internet 'n mens gee tot 'n verskeidenheid hulpmiddele en gespreksgroepe oor die Klassieke, maak nou 'n lewenslange betrokkenheid en interaksie met die Klassieke moontlik.

Die Klassieke is wesenlik 'n hermeneutiese wetenskap wat ten doel het om onderdele en aspekte van die antieke in terme van die omvattende geheel wat daardie wêreld uitmaak, te verstaan. Belangrike intellektuele vaardighede in dié verband is rekonstruksie en integrasie. Juis omdat ons gegewens oor ' $n$ bepaalde antieke tydvak of situasie dikwels gebrekkig is, word 'n mens gedwing om die geheel uit die deel af te lei, om enkelfeite in die lig van groter betekenisverbande te probeer verstaan. Dit is soos om 'n legkaart of mosaïk te probeer voltooi waarvan stukkies ontbreek; of, om ' $n$ ander beeld te gebruik, soos om 'n hele dinosourus uit 'n paar beenfossiele te rekonstrueer. ${ }^{20}$ 'n Goeie klassieke opvoeding leer 'n mens die belang van detail, maar ook om dit in sinvolle betekenisverbande te probeer verstaan. Om feite met aandag te kan bestudeer, om met kreatiwiteit en verbeelding verbande te kan lê, om ' $n$ betekeniswêreld uit ' $n$ teksfragment te kan rekonstrueer: dit is waardevolle

20 Ons vind hierdie beeld reeds in die antieke Griekse spreuk żł ô die leeu", 'n spreuk wat N P van Wyk Louw ook krities benut in sy gedig "Ex unguine leonem" uit die bundel Tristia (Louw 1981:233):

Ek kan nie opsom: nie 'n lewe, 'n gesprek,

'n tydperk of ' $n$ eeu.

Die klou dui al die dier aan, is gesê -

maar ís nog nie die leeu .... 
intellektuele vaardighede in 'n moderne wêreld waar ' $n$ mens met feite en inligting oorlaai word.

Hierdie algemene hermeneutiese vaardighede word natuurlik nie net deur 'n bestudering van die Klassieke ontwikkel nie; hulle is mutatis mutandis inderdaad kenmerkend van die humaniora in die algemeen. Waarin lê dus die besondere waarde en blywende aantrekkingskrag van die Klassieke opgesluit?

Ons het gesien dat die opvatting "klassieke" as normatiewe kultuurgoedere in 'n postmoderne wêreld weinig aftrek kry. Die term "klassieke"-hetsy in die geskiedenis, die letterkunde, kuns of musiek-het egter 'n ander belangrike konnotasie: dit dui juis op die kultuurgoedere wat met verloop van tyd gesif is en hulle waarde oor lang tydperke en in verskillende tydvakke bewys het, en gevolglik as belangrike vertrekpunte in hulle onderskeie velde beskou moet word. Indien die akademie en veral die humaniora waardegeoriënteerd is, behoort ons juis te konsentreer op dié kultuurmomente en -produkte wat van fundamentele en sleutelwaarde in ons tradisie was en is. ${ }^{21}$ Aan hierdie voorwaarde voldoen die Griekse en Latynse klassieke by uitnemendheid.

Meer spesifiek lê die inhoudelike waarde van die Klassieke miskien in die jukstaposisie van die bekende en vreemde wat ons daarin aantref. ${ }^{22}$ Ons herken onsself in die allesvernietigende smart van helde soos Achilles en Aeneas by die dood van hulle boesemvriende; in Sapfo en Catullus se meegesleur word deur die oorweldigende mag van die liefde; in Antigone se dilemma om tussen haar gewete en die staat te moet kies; ons kan ons identifiseer met die Griekse natuurfilosowe se spekulasies oor die ontstaan en die grense van die kosmos; met antieke ingenieurs se integrasie van skoonheid en funksionaliteit; met Demostenes en Cicero se stryd om die voortbestaan van demokratiese waardes te beskerm teen die aanvalle van magtige diktators; met Augustinus se ervaring van tot ruste kom in God in 'n onrustige wêreld. In hierdie selfherkenning kom ons ook tot self-insig, verstaan ons onsself beter. $\Gamma \nu \hat{\omega} \theta \iota$ $\sigma \alpha v \tau o \dot{\nu}$, "Ken jouself!" was juis een van die belangrikste Griekse morele spreuke. Tegelykertyd bly die antieke vir ons 'n verrassende en vreemde wêreld: die Grieke en Romeine se opvattinge oor god, die wêreld en die mens, oor die rol van die noodlot, oor familiale verhoudinge en seks, oor standverskille en slawerny, en nog vele meer, verskil aansienlik van ons eie. Hierin lê juis die aantrekkingskrag en belang van die Klassieke. Ek haal graag Jasper Griffin, professor in Klassieke by Oxford, aan:

To see that such things can be true of people whom in some ways we find intelligible and recognizable can help to deliver us from the tyranny of the present, from the assumption that our own habits of action and thought are really inescapable, and from the idea that there are no alternatives. That is the liberating power of the past (Boardman, Griffin \& Murray 1988:8).

21 Vgl. De Dijn 1997.

22 Vgl. Jasper Griffin se inleiding tot The Oxford history of Greece and the Hellenistic world (Boardman, Griffin \& Murray 1988:1-8). 
Dit, dames en here, is Grieks en die Klassieke vir my.

\section{BIBLIOGRAFIE}

Boardman, J, Griffin, J \& Murray, O (eds) 1988. The Oxford history of Greece and the Hellenistic world. Revised ed. of vol. 1 of History of the classical world (1986). Oxford; New York: Oxford University Press.

Boswell, J [1799] 1934-50. Boswell's Life of Johnson. 6 vols. Ed. G B Hill. Rev. L.F. Powell. Oxford: Clarendon.

De Dijn, H 1997. The university and the human sciences. Referaat gelewer by die Stellenbosch Forum op 20 Augustus 1997.

Dover, K J (ed) 1968. Aristophanes: Clouds. Oxford: Clarendon Press.

Erler, M 1994. Die Schule Epikurs. In Grundriss der Geschichte der Philosophie: die Philosophie der Antike. Vol. 4/1, Die hellenistische Philosophie. Völlig neubearbeitete Ausgabe, hrsg. H Flashar, 203-380. Basel: Schwabe \& Co.

Guthrie, W K C 1969. A history of Greek philosophy. Vol. 3, The fifth-century enlightenment. Cambridge: Cambridge University Press.

1975. A history of Greek philosophy. Vol. 4, Plato: The man and his dialogues: Earlier period. Cambridge: Cambridge University Press.

Highet, G 1967. The classical tradition: Greek and Roman influences on Western literature. Reprint (with corrections). Oxford: Oxford University Press.

Hornblower, S \& Spawforth, A (eds) 1996. The Oxford classical dictionary. 3d ed. Oxford/New York: Oxford University Press.

Joint Association of Classical Teachers. 1984. The world of Athens: An introduction to classical Athenian culture. Joint Association of Classical Teachers Greek course. Cambridge: Cambridge University Press.

Jonson, B 1623. To the memory of my beloved, the author Mr. William Shakespeare and what he hath left us. In Herford, C H, \& Simpson, P \& E (eds), Ben Jonson. Vol. 3. Oxford: Clarendon, 1947.

Konstan, D et al. 1998. Philodemus: On frank criticism. Society of Biblical Literature text and translation series. Atlanta, Georgia: Scholars Press.

Louw, N P van Wyk. 1981. Versamelde gedigte. Kaapstad: Tafelberg/Human \& Rousseau.

Marrou, H I 1982. A history of education in antiquity. Trans. G. Lamb. Wisconsin Studies in Classics. Madison: University of Wisconsin Press.

Rossouw, H W 1980. Wetenskap, interpretasie, wysheid. Gasvoorlesings gelewer aan die Universiteit van Port Elizabeth 14-16 Augustus 1979. Seminare, simposia en lesings B7. Port Elizabeth: Universiteit van Port Elizabeth.

-----. 1993. Universiteit, wetenskap en kultuur: Opstelle oor die krisis, uitdagings en geleenthede van die moderne universiteit. Saamgestel en ingelei deur A van Niekerk. Kaapstad: Tafelberg. 
1997. Die behoud van die akademiese etos. Langenhoven-lesing gelewer aan die Universiteit van Port Elizabeth op 25 September 1996. Seminare, simposia en lesings B24. Port Elizabeth: Universiteit van Port Elizabeth.

Schoonees, P C et al. (reds) 1950-. Woordeboek van die Afrikaanse taal. Pretoria: Die Staatsdrukker; Stellenbosch: Buro van die WAT.

Shand, S J 1916. The making of a university. A lecture delivered at Stellenbosch on the occasion of the passing of the University of Stellenbosch Acts. Students' quarterly (Stellenbosch), June, 1-12.

Smuts, F 1960. Classical scholarship and the teaching of classics at Cape Town and Stellenbosch. Acta Classica 3:7-31.

1966. Die Klassieke op Stellenbosch. Nuusbrief/Newsletter [Departemente van Grieks en Latyn, Universiteit van Stellenbosch] 11(3):10-53, 87. 